\title{
LAS PINTURAS GÓTICO-MUDÉJARES DE LA CAPILLA DE LA QUINTA ANGUSTIA (SEVILLA)
}

\author{
POR JOSÉ Ma MEDIANERO HERNÁNDEZ
}

Estudio histórico-artístico de estas interesantes pinturas que decoran los entrelazos de la bóveda central de tipo mudéjar de esta capilla. Se intenta asimismo ofrecer una interpretación iconográfica sobre su posible significado simbólico de "Psicomaquia" -- lucha de Vicios y Virtudes -- aunque sin despreciar nunca su alto valor decorativo parangonable con otras decoraciones murales al uso en época de Pedro I de Castilla e inmediatamente después de su reinado.

An historical and artistic study of the interesting paintings which adorn the interlacing of the mudejar style central vault of the Quinta Angustia Chapell. An attempt is made at offering a iconographic interpretation of their possible symbolic significance -- the struggle between Vices and Virtues -- but at a the same time not depreciating their highly decorative value, comparable to other wall decorations in use at the time of Pedro I of Castille and immediately following his reign.

La Capilla de la Quinta Angustia, aneja a la actual parroquia sevillana de la Magdalena - antigua iglesia del Convento de San Pablo, insignia monástica de los dominicos en la capital hispalense-, ofrece multitud de atractivos histórico-artísticos, que van desde su propia estructura arquitectónica hasta las obras de escultura y pintura de primer orden que contiene. A estas líneas compete el análisis de unas manifestaciones artísticas si queremos menores respecto a la importancia del conjunto, pero en absoluto de escaso interés respecto a la interpretación unitaria de la capilla en su origen y de su valor testimonial como fórmula decorativa estilísticamente híbrida desarrollada en la Sevilla bajomedieval.

Como es sabido, esta capilla es el único resto de entidad conservado de la antigua iglesia medieval dominica, reedificada más tarde durante la etapa bartoca por Leonardo de Figueroa. En verdad, se trata de tres capillas probablemente independientes antaño 
que daban a la nave del templo, unidas luego longitudinalmente y constituidas más tarde en sede de la conocida cofradía hispalense de la Quinta Angustia .

Hacia 1706 se verificaron obras que enmascararon el aspecto gótico-mudéjar de las tres crujías con pinturas y yeserías barrocas ${ }^{2}$. Luego, en 1851 , se ejecutaron nuevas obras de exorno con el añadido de retablos neoclásicos y pinturas de distinto signo ${ }^{3}$. El resultado de estas y otras labores menores fue el ocultamiento de las bóvedas de lazo originales con casquetes rebajados en yeso, tal y como puede observarse en un dibujo de Joaquín Guichot de mediados del siglo pasado (Lám. 1).

Posiblemente en 1914 la Hermandad de la Quinta Angustia decidió eliminar el añadido de la bóveda más cercana a los pies de la iglesia y dejarla al descubierto para dar así mayor espacio al espectacular grupo del Descendimiento que configura el conocido paso de la Cofradía ${ }^{4}$. El añadido formaba un falso techo que se constituía en suelo de un pequeño almacén o trastero entre éste y el intradós de la bóveda primitiva. El 3 de Enero de 1915 el Cabildo General de la Hermandad acordó, después de analizar el proyecto del Arquitecto D. Pablo Gutiérrez Moreno, desembarazar esta bóveda de dicho aditamento, lo cual significa que la voluntad de esta iniciativa debe ser lógicamente anterior a la redacción del proyecto por parte del arquitecto referido ${ }^{5}$. En las labores previas de reconocimiento y no en 1917, como afirman Gutiérrez Moreno y Alejandro Guichot, hubieron de descubrirse las pinturas de la bóveda central, posiblemente en el antedicho año de $1914^{6}$.

Ahora bien; las pinturas no quedaron al descubierto totalmente hasta las obras de restauración dirigidas por el ya mencionado arquitecto Gutiérrez Moreno, llevadas a cabo desde el 5 de Marzo de 1917 al 18 de Marzo de 1919, como recuerda una lápida conmemorativa colocada junto a la puerta de la capilla que comunica con el interior de la iglesia?

1. La cuestión de la estructura arquitectónica y su engarce con la antigua iglesia medieval resulta un tema tan atractivó como complejo. No voy a entrar en él por ser otro el motivo de este artículo; baste decir que todos los autores abundan en afirmar la inequívoca inclusión de estas capillas dentro del contorno perimetral del templo gótico-mudéjar.

2. GESTOSO Ý PEREZ, J. Sevilla Monumental y Artística Sevilla, 1889-92 Tomo III Pág. 380.

3. IBIDEM Pág. 380 y GUICHOT Y SIERRA, A. El Cicerone de Sevilla Sevilla, 1925 Tomo I Pág. 178.

4. Vid. GUTIERREZ MORENO, P. "La Capilla sevillana de la Quinta Angustia" en Archivo Español de Arte y Arqueología Tomo V, 1929 Pág. 233.

5. RODRIGUEZ-CASO DOSAL, L. Anales de 1500 a 1976 de la Hermandad de la Quinta Angustia Sevilla, 1978. Ejemplar mecanografiado y encuadernado depositado en la Casa-Hermandad. Pág. 113.

6. El dato viene avalado, además de por los trabajos anteriores a la obra de restauración, sobre todo por las fechas de algunas fotografías tomadas por D. Francisco Murillo Herrera - por entonces Catedrático de Teoría de la Literatura y de las Artes de la Universidad hispalense - conservadas hoy en el Archivo Fotográfico del Departamento de $\mathrm{H}^{\mathbf{a}}$ del Arte de la Universidad de Sevilla. En los sobres y fichas correspondientes a los pesados negativos de cristal aparece como fecha más temprana el 1 de Septiembre de 1914, prueba inequívoca del descubrimiento fehaciente de las pinturas ya en este año y de que D. Francisco Murillo fue el primer estudioso de las mismas. Vid. GUICHOT Y SIERRA, A. Opus cit. Tomo II Págs. 14-15.

7. Vid. RODRIGUEZ-CASO DOSAL, L. Opus cit. Págs. 118-9 y GUICHOT Y SIERRA, A. Opus cit. Tomo I Págs. 178-9 y Tomo II Pág. 14. 
La bóveda central que contiene las pinturas es una hermosa cubierta a modo de cúpula de lazo de tradición hispano-musulmana en fábrica de ladrillo y soportada por doble juego de trompas ${ }^{8}$. En los espacios determinados por la intersección de los lazos se localiza la decoración pictórica de distintos motivos según la distribución; en líneas generales, puede decirse que en el friso inferior se disponen motivos vegetales de hojas, en los encasamientos inmediatamente superiores, de contorno irregular, aparecen los temas figurativos y, ajustándose a los espacios dejados por el entrecruzamiento de lazos hacia arriba, ornato de tipo ataurique mudéjar como se verá más detenidamente luego (Lám. 2). Diríase que estas pinturas vienen a desempeñar el papel decorativo propio de la decoración pictórica en artesonados de tradición morisca o de los azulejos aplicados en bóvedas similares 9 .

Los colores utilizados son el negro y el ocre, con la inclusión esporádica del rojo y, más aún, del blanco. Los autores de principios de siglo hablan de "frescos", pero debe ser más que una determinación técnica una asimilación nominal con mural. No contamos con análisis fiables, pero no sería de extrañar que se tratase de una técnica mixta con amplia participación del temple sobre mortero calizo ${ }^{10}$.

El estado de conservación no resulta insatisfactorio, sobre todo si tenemos en cuenta que no nos consta restauración desde la realizada por Gutiérrez Moreno antes comentada. En la actualidad algunas filtraciones y humedades han dañado ciertas zonas, problema atajado por la reciente remodelación de las cubiertas del edificio. Hacia el lado izquierdo de la bóveda se observan algunas superficies pictóricas picadas, labor que hubo de ejecutarse durante las reformas barrocas. Sin embargo, el estado actual de conservación junto con las fotografías y láminas pintadas, al parecer a raíz del descubrimiento, conservadas en el Archivo Fotográfico del Departamento de $\mathrm{H}^{\mathrm{a}}$ del Arte de la Universidad de Sevilla, que ofrecemos en el apartado gráfico, permiten un adecuado estudio del conjunto.

En síntesis, el repertorio pintado podría dividirse en tres grandes grupos: motivos figurativos; representaciones heráldicas y decoración de inspiración vegetal. Comenzaré por el primero distinguiendo los siguientes tipos:

1) Figuras humanas.- Contamos con dos, una masculina y otra femenina. La primera es un mancebo sonriente, en actitud móvil, como si de un paso de danza se

8. Sobre las características de fábrica y constructivas de esta bóveda Vid. GUTIERREZ MORENO, P. Opus cit. Págs. 236-241 passim.

9. Con toda probabilidad, sería la aplicación de pintura una fórmula usual de ornato más económica y resolutiva que la cerámica vidriada en los edificios mudéjares, también en los de carácter religioso, ya que su temática de motivos geométricos y vegetales no entraba en conflicto con los postulados cristianos. Así, por citar sólo un ejemplo cercano, en una de las bóvedas de la notable iglesia de Sta. María de la Oliva en Lebrija (Sevilla), donde asimismo se observan restos pictóricos de este cariz. Vid. MORALES, A. ET ALT. Guía Artística de Sevilla y su Provincia Sevilla, 1981 Pág. 325 e Inventario artístico de Sevilla y su Provincia Tomo II Madrid, 1985 Pág. 532.

10. Gutiérrez Moreno, el restaurador de la bóveda y pinturas entre 1917 y 1919 habla de decoraciones "pintadas al temple". Opus cit. Pág. 245. 
tratase, de tres cuartos en posición de marcha y un brazo "en jarras" apoyado en la cadera. Luce un peinado peculiar, más femenino que masculino, con el pelo recogido a ambos lados de la cabeza por redecillas. Viste un jubón, ajustado al cuello y exageradamente a la cintura, con amplias mangas colgantes hacia los codos. Las piernas las cubre con ceñidas medias y los pies por graciosas calzas livianas. En la mano libre porta una especie de copa o peana sobre la que reposa un objeto esférico. El fondo es oscuro con decoración de cardina de bordes redondeados; el marco a base de líneas de puntos negros (Lám. 3).

La figura femenina, por el contrario, mantiene una actitud estática y frontal. Parece como esbozada, quizás sin terminar, pues los trazos son sumarios y el rostro está sin pintar; es una "dama sin rostro". Viste un ampuloso vestido, algo escotado, con holgadísimas mangas que se recogen a la altura de la muñeca. Su peinado aparece sólo apuntado, con líneas generales, sin poderse describir de manera certera. Una mano, asimismo esbozada, la apoya sobre su pecho y otra la levanta para sostener un objeto circular que puede relacionarse con el mejor terminado que porta la figura masculina. El fondo se configura de manera similar (Lám. 4).

2) Centauros de figura femenina.- Son dos, ambos con torso de mujer y bípedos, esto es, con dos patas. Uno porta en una mano un escudo y. en la otra esgrime una rotunda espada. Viste un jubón ceñido al cuello y a la cintura de forma similar al comentado en la figura masculina anterior, aunque cae en larga falda de curvilíneo drapeado por la parte inferior. Su rostro sonriente se encuadra por cabellos en largos mechones, con raya en medio y recogidos hacia atrás en una especie de moño. Las patas bestiales de este centauro con torso de mujer parecen corresponder a las traseras de un león, así como su cola. El fondo, en negro, aparece decorado por hojas y flores (Lám. 5).

La otra figura de este tipo, en cambio, porta un arco, manteniendo la mano libre levantada. El vestido es similar a su correspondiente anterior, así como su peinado. Sin embargo, la parte de cuerpo bestial pertenece claramente a la de un caballo. En ambas la diferenciación sexual entre la parte humana y la animal es notoria. En el fondo aparecen las usuales hojas alargadas, aunque aquí no se aprecian las flores que se consignaron en la anterior (Lám. 6).

3) Dragones.- Se distinguen cinco representaciones: en general tienen la cabeza canina, similar a la del lobo, con sólo dos patas salvo uno, largo cuello entre serpiente y felino, y alados excepto uno. Este último se caracteriza por su gran cabeza de lobo, muy fiera, con patas de león y cola del mismo animal (Lám. 7).

Entre los alados pueden diferenciarse dos tipos: uno de patas de ave y cola enroscada de reptil (Láms. 8 y 9) y otro con patas de felino, que en un ejemplar son hasta cinco (Láms. 10 y 11). En el fondo negro suelen aparecer las características hojas alargadas y flores decorativas en color ocre claro.

4) Cinocéfalo.- Se trata, efectivamente, de una figura antropomorfa con cabeza de perro. Las piernas y la cabeza están figuradas de perfil, pero el tronco llevado 
por una rigurosa "Ley de la frontalidad" aparece de cara al espectador, así como la mirada del monstruo. Lleva ambos brazos levantados y en sendas manos aprieta un objeto difícil de identificar. En el fondo se observan las usuales hojas alargadas de contorno sinuoso redondeado (Lám. 12).

Por otra parte, en la zona que sería hipotética cabecera de la capilla cuando ésta se comunicaba con la iglesia medieval se aprecian tres escudos: dos son iguales, con un par de lobos blancos sobre campo azul enmarcados por bordura clara con sotueres dorados (Lám. 13). El otro se configura por medio de cuatro cuarteles ocupados alternativamente por leones rampantes púrpuras y aspas doradas (Lám. 14). Este último corresponde a la familia Medina, mientras que el primero es timbre de la familia Ayala-Salcedo, ambas de notoria influencia en la Andalucía y tierras castellanas de la época, como se verá más detenidamente al final de este trabajo ${ }^{11}$.

En cuanto a los paneles con motivos de inspiración vegetal podemos apreciar dos tipos fundamentales: uno de abolengo claramente hispano-musulmán, cercano a lo nazarita granadino con las típicas hojas alargadas y vainas curvilíneas, en conjuntos muy tupidos (Lám. 15); otro de carácter gótico, tanto en las hojas de las figuraciones antes descritas como en los registros alargados de la zona inferior de la bóveda, con hojas denticuladas parecidas a las del roble enlazadas por tallos o vástagos curvilíneos con hojas y flores tipo cardina (Lám. 16).

Una vez descritas, hora es ya de ensayar una explicación temática de estas pinturas. Los autores que hasta ahora han tratado sobre ellas no aciertan a dar una explicación definida. Las afirmaciones van desde considerarlas de "misterioso simbolismo" hasta, incluso, dudar si no son, por el contrario, meramente decorativas, sin contenido simbólico ${ }^{12}$. Intentaré aquí justificar la interpretación de estas pinturas como una lucha simbólica entre Vicios y Virtudes, expresado por primera vez por Prudencio y formalizado artísticamente por la plástica medieval ${ }^{13}$.

Como es sabido, durante los siglos XIV y XV se va progresivamente abandonando la iconografía tradicional del Vicio pisado por la Virtud con sus atributos y se prefiere la versión del propio combate, por considerar la literatura religiosa y moral de la Baja Edad Media que no era tan fácil la victoria de la Virtud, además de conectar con el ambiente de justas y torneos caballerescos tan en auge en los últimos siglos del medievo. Las representaciones iconográficas de las Virtudes

11. Sobre la identificación heráldica de estos escudos Vid. GARCIA CARRAFA, A. y A. Diccionario Heráldico y Genealógico de apellidos españoles y americanos Salamanca, 1935 Tomo LV Págs. 172-3 y Tomo XII pág. 246 y, también, ARGOTE DE MOLINA, G. Nobleza del Andalucía Ed. del Instituto de Estudios Giennenses de 1957 Págs. 158 y 303.

12. Vid. por ejemplo: GUTIERREZ MORENO, P. Opus cit. Pág. 243; GUICHOT Y SIERRA, A. Opus cit. Tomo II Págs. 14-15 y HERNANDEZ DIAZ, J. "La Parroquia sevillana de Sta. María Magdalena" en el Boletín de la Real Academia de Bellas Artes $n^{\circ}$ VIII Sevilla, 1980 Pág. 210.

13. MATEO GOMEZ, I. Temas Profanos en la Escultura Gótica Española. Las Sillerias de Coro Madrid, C.S.I.C., 1979 Págs. 184-5; REAU, L. Iconographie de l'Art Chretien París, Presses Universitaires de France, 1957 Tomo I Págs. 176-80; SEBASTIAN LOPEZ, S. Mensaje del Arte Medieval Córdoba, Ed. "El Almendro", 1984 Págs. 112-17 e IDEM Iconografia Medieval San Sebastián, 1988 Págs. 285-292 passim. 
suelen montar sobre caballos guerreros y arremeten contra los Vicios, jinetes también, pero de animales simbólicos o monstruos referentes a ellos. Así se narraba en los sermones, se representaba en el teatro de la época y aparecía en las imágenes, como en los libros ilustrados por Simon Vostre, especialmente en el conocido poema de Gringoire titulado Château de Labour ${ }^{14}$.

Las pinturas de la Capilla de la Quinta Angustia bien pudieran ser una versión local y reelaborada de este tema, pues las variantes sobre el mismo son numerosísimas ${ }^{15}$, hasta el punto de engendrarse composiciones confusas en las cuales, como advierte Mâle, es difícil saber distinguir cuál representación es un Vicio y cuál una Virtud ${ }^{16}$.

En el caso de las pinturas que nos ocupan, parece lógico suponer como representación de las Virtudes a las figuras de centauros de tipo femenino mientras que los Vicios o principios de mal vendrían figurados por las restantes representaciones. A lo largo de la Edad Media el motivo mitológico del centauro va depurándose de la carga negativa clásica y se trueca en bastantes ocasiones en alegoría positiva ${ }^{17}$. Más claro aún: en la sillería de la Catedral de Oviedo aparece un centauro benéfico que lucha contra un dragón alado ${ }^{18}$. En estas pinturas de la Capilla de la Quinta Angustia las Virtudes tomarían la forma del centauro con torso de mujer por su carácter femenino como tales virtudes.

Los dragones requieren menor elucidación; son las figuras más abundantes en estas pinturas y, sin duda, deben de ser clasificados dentro de las representaciones maléficas, valoración ya patente desde las mitologías más antiguas como la egipcia, en cuyo contexto cultural son símbolo del mal vencido por Osiris ${ }^{19}$. Durante la Edad Media adquieren la cualidad añadida de enemigo por excelencia del bien; vienen a convertirse en el símbolo arquetípico del descomunal combate, donde el dragón ha de ser vencido por el representante de los principios benéficos ${ }^{20}$, lo cual encaja perfectamente en el argumento de una lucha encarnizada entre Vicios y Virtudes.

En cuanto al cinocéfalo, es decir al hombre con cabeza de perro -monstruo tradicional del bestiario medieval que aparece ya en la portada de Vezelay ${ }^{21}$-, tendría también una interpretación negativa, como símbolo impuro, de los pecadores

14. MÂLE, E. L'Art religieux de la fin du Moyen Âge en France París, 1922 Págs. 336-8; SEBASTIAN LÓPEZ, S. Iconografía Medieval Opus cit. Págs. 305-7 e Ídem "En torno a la iconografía de la Virtud y del Vicio en la Baja Edad Media" en Homenaje al Prf. Dr. Hernández Diaz Universidad de Sevilla, 1982 Tomo I Págs. 185-93.

15. Acerca de la evolución del tema desde sus orígenes hasta fines de la Edad Media Vid. el valioso libro de KATZENELLENBOGEN, A. Allegories of the Virtues and Vices in Medieval Art. From early christian times to the thirteenth century Nueva York, 1964 (1* Ed. 1939).

16. MÂlE, E. Opus cit. Pág. 340.

17. Incluso el centauro-sagitario, con el arco en la mano, pasa a simbolizar a Cristo como cazador de almas. Vid. REVILLA, F. Diccionario de Iconografía y Simbología Madrid, 1995 Pág. 92.

18. MATEO GOMEZ, I. Temas Profanos en la Escultura Gótica Española Opus cit. Pág. 132.

19. YARZA, F. C. Diccionario de Mitología Barcelona, 1991 Pág. 59 . Vid. también CHEVALIER, J. y GHEERBRANT, A. Diccionario de los símbolos Barcelona, 1986 Pág. 428.

20. CIRLOT, J. E. Diccionario de símbolos Barcelona, 1978 Pág. 175-6.

21. SEBASTIAN LOPEZ, S. Iconografía Medieval Opus cit. Pág. 52. 
que vuelven sobre sus pecados ${ }^{2}$. Las dos figuras humanas, la masculina y la femenina, ricamente vestidas y con aire cortesano, parecen encarnar una contraposición sexual a todas luces negativa para el pensamiento medieval. Portan ambas un objeto esférico que podría identificarse con una manzana; en tal caso serían una simbolización del amor licencioso y del triunfo de los instintos sensuales sobre la razón ${ }^{23}$.

La representación de la disputa entre Vicios y Virtudes en una capilla de patronazgo nobiliar, como prueban los dos escudos asimismo pintados, resulta una temática perfectamente adecuada al carácter del ámbito. Es más, nos consta que en los oratorios y estancias de las casas de la nobleza de la Andalucía cristiana bajomedieval un recurso temático común, entre distintos repertorios puramente decorativos, era la representación simbólica de virtudes y otros principios benefactores que vendrían a significar la verdadera vocación de los caballeros de la época ${ }^{24}$.

Ahora bien, aun admitiendo la posibilidad de esta interpretación iconológica, parece evidente por el planteamiento del conjunto y por el encuadre de las figuras que sobre la significación prima una intención decorativa. No ha lugar aquí entrar en la manida y parcial disquisición sobre si todas y cada una de las representaciones medievales tienen una intención simbólica o, por el contrario, son simples elementos decorativos ${ }^{25}$. En este caso parece evidente que las pinturas están concebidas como complemento suntuario de la cubrición de la capilla, relegando a un segundo plano el sentido de mensaje simbólico.

Además es necesario no olvidar el afán repetitivo de los artesanos y artistas medievales, sobre todo en la parcela ornamental, hasta el punto de que en muchas ocasiones imitaban motivos y figuras sin conocer claramente su significado real, simplemente porque resultaban hallazgos afortunados de otros artistas o porque cuadraban perfectamente con el esquema deseado en la nueva obra ${ }^{26}$. Por citar una referencia a propósito, Olivier Beigbeder afirma que la caza del ciervo por parte de centauros-sagitarios en muchas ocasiones no es más que ún elemento decorativo, presente sobre todo en tejidos 27 .

Precisamente, tanto la presencia de esta figuración como là rígida compartimentación a base de encuadres geométricos, formados por franjas con puntos negros, dentro

22. Vid. CHAMPEAUX, G. y STERCKX, J. Introduction au Monde des Symboles Col. Zodiaque, 1966 Págs. 252-4 y REAU, L. Iconographie de l'Art Chretien Opus cit. Tomo I Págs. 109 y 128.

23. Vid. TERVARENT, G. de Attributs et Symboles dans l'Art Profane (1450-1600) Ginebra, 1958 Págs. 311-12; CHEVALIER, J. y GHEERBRANT, A. Opus cit. Pág. 689 y PEREZ RIOJA, J. A. Diccionario de Símbolos y Mitos Madrid, 1988 Pág. 287, por ejemplo. También la reciente publicación de QUIÑONES, A. M'. El Simbolismo vegetal en el Arte Medieval Madrid, 1995 Págs. 112-14.

24. Posiblemente el ejemplo más destacado sean los zócalos pintados de la casa que cobijó antaño el Museo Arqueológico de Córdoba. Vid. MEDIANERO HERNANDEZ, J. M". "Aproximación evolutiva a la Pintura Gótica en el antiguo Reino de Córdoba" en Ariadna (Revista de Investigación) n 61989 Págs. 52-56.

25. Vid. en este sentido, por ejemplo, el libro ya clásico de WEISBACH, W. Reforma religiosa y Arte Medieval Madrid, 1949 Pág. 100.

26. Cfr. SEBASTIAN LOPEZ, S. Mensaje del Arte Medieval Opus cit. Pág. 105.

27. BEIGBEDER, O. Lexique des Symboles Col. Zodiaque, 1969 Pág. 142. 
de los cuales se colocan las figuras, hacen pensar efectivamente en tejidos de la época ${ }^{28}$. Baltrusaitis cita en Occidente tejidos del siglo XIII que combinan, dentro de polilóbulos, figuras góticas con monstruos enfrentados y afirma que las sederías españolas e italianas de esta etapa repiten este esquema de entrecruzamientos con relleno de los espacios intermedios a base de seres fantásticos o criaturas grotescas ${ }^{29}$.

Desde luego, en España existió una verdadera predilección por este tipo de tejidos de ornato geométrico y lineal con figuraciones inspirados sin duda en modelos islámicos ${ }^{30}$. No sería extraño, por consiguiente, que los autores de las pinturas de la Capilla de la Quinta Angustia se basaran en tejidos de ese tenor frecuentes en la Sevilla del momento, imitando, como afirma Baltrusaitis, no sólo “el armazon geométrico, sino también...el tejido entero, resplandeciente con sus monstruos" ${ }^{31}$. De nuevo vuelvo a insistir que en este caso la simbología quedaría en un segundo plano frente a una predominante intención decorativa, combinando motivos tomados de elencos presentes en tejidos, cerámica o marfiles de raíz islámica, por citar sólo unas posibilidades.

En realidad, estamos ante el amplísimo y mal conocido repertorio de la decoración gótico-mudéjar desarrollada en los últimos siglos medievales en Andalucía. A pesar de lo mucho perdido, es indudable que la mayoría de pinturas murales en aquel lapso de tiempo correspondería a zócalos y murales decorativos donde motivos figurados cristianos convivirían con "aliseres", lacerías y ornato tipo ataurique de raigambre islámica ${ }^{32}$.

En el caso de las pinturas aquí tratadas esta combinación es evidente, con ornato vegetal que recuerda tanto a lo nazarí granadino como al mudéjar toledano. Se ha apuntado en este sentido, por algunos autores, la similitud de concepción de esta bóveda de la Capilla de la Quinta Angustia con la bóveda de la Capilla de San Jerónimo de la Concepción Francisca de Toledo, en este caso decorada no por pinturas sino por azulejos ${ }^{33}$. Si bien, en otras muchas obras mudéjares toledanas pueden hallarse similitudes; también en los detalles, como en el tema decorativo de hojas de vid o roble con tallos enlazados que encuentra ecos flagrantes en las

28. De hecho, ya D. Francisco Murillo Herrera, el primer autor que estudió estas pinturas, reparó en la similtud con tejidos orientales y afirmó que los temas decorativos estaban "tomados del.arte copto marcadamente”. Vid. GUICHOT Y SIERRA, A. Opus cit. Tomo II Pág. 15.

29. BALTRUSAITIS, J. La Edad Media Fantástica Madrid, 1983 Págs. 100-104.

30. Vid., por ejemplo, los modelos de las Láms. LXVI y LXVII del libro de KOECHLIN, R. y MIGEON, G. Arte Musulmán (Cerámica, Tejidos, Tapices) Barcelona, 1930 y los de influencia islámica italianos del siglo XIII en FLEMMING, E. Tejidos Artísticos Barcelona, 1928 Láms. Págs. 49-51.

31. Opus cit. Pág. 108.

32. Este tipo de pintura mural esencialmente ornamental se extendía tanto a ámbitos religiosos como civiles, constituyendo el trabajo más usual entre los pintores del periodo. Vid. en este sentido mi Tesis Doctoral inédita La Pintura Trecentista en Andalucía Sevilla, 1987 Tomo I Pág. 49.

33. GUTIERREZ MORENO, P. Opus cit. Pág. 239 y GUERRERO LOVILLO, J. Guías Artísticas de España. Sevilla Barcelona, 1962 Pág. 126. 
yeserías de la Sinagoga del Tránsito y el "Salón de Mesa", por citar sólo un aspecto parcial y dos ejemplos ${ }^{34}$.

En verdad estas pinturas hispalenses están dentro de lo que Pavón Maldonado llama "Fase granadina de la decoración toledana", que se sitúa cronológicamente entre fines del siglo XIV y comienzos del XV, donde se imbrican motivos mudéjares toledanos con recursos procedentes de la yesería granadina y pequeñas figuraciones cristianas ${ }^{35}$. De esta manera el análisis estilístico-decorativo nos conduce ineludiblemente a la datación de la obra que nos ocupa, porque, en efecto, la síntesis enriquecedora entre el arte musulmán y el cristiano nacida en obras mudéjares del siglo XIII será la que presida los palacios castellanos y andaluces decorados por artífices toledanos o artesanos vinculados a los mismos durante el reinado de Pedro I de Castilla ${ }^{36}$.

De hecho sabemos que D. Pedro fue un gran benefactor del Convento de San Pablo sevillano y que incluso las noticias de donaciones en su testamento podrían dar pie a pensar que fuera tras su muerte cuando se levantaron las tres crujías de la actual Capilla de la Quinta Angustia ${ }^{37}$. Al mismo tiempo, la plasmación de los escudos de las familias Medina y Ayala traen inmediatamente a la memoria vinculaciones estrechas con el monarca llamado por unos Cruel y por otros Justiciero.

No parece necesario insistir en los miembros de la familia Ayala relacionados con D. Pedro, comenzando por el famoso cronista y siguiendo por todos aquellos que desempeñaron un importante papel fundamentalmente en la historia toledana de fines del siglo XIV y comienzos del XV ${ }^{38}$. Incluso al constatar la presencia del escudo de la familia Medina se desliza la tentación de adjudicar la capilla a D. Gonzalo Núñez de Medina, Despensero Mayor de Pedro I y Tesorero Mayor de la casa de la Moneda de Sevilla, en cuya heredad de Las Marismas llamada "La Atalayuela" iba frecuentemente a cazar el rey y luego mandó construir allí un palacete ${ }^{39}$.

Sin embargo, no disponemos hasta la fecha de una noticia documental fiable que pueda asegurar esta pretensión, tanto más cuanto que el patrocinio de capillas en el Convento de San Pablo de los Medina, muy unidos al gobierno de la ciudad, fue realmente prolija ${ }^{40}$. En este intervalo de tiempo entre el ocaso del siglo XIV y las primeras décadas del siguiente tenemos datos de varios miembros de la familia muy cercanos en sus patronazgos al monasterio dominico.

34. Cfr. FLAMENT, A. y M. Toledo León, Everest, 1967 Láms. 107 y 110.

35. Arte Toledano: islámico y mudéjar Madrid, 1988 Págs. 162-66.

36. IBIDEM Pág. 235.

37. Cfr. HERNANDEZ DIAZ, J. "La Parroquia sevillana de Sta. María Magdalena" Opus cit. Págs. 206 y 210. Sobre las limosnas al convento por parte del rey Vid. ORTIZ DE ZUÑIGA, D. Anales Eclesiásticos y Seculares de la M. N. y M. L. ciudad de Sevilla Madrid, 1795 Tomo II Págs. 135-6 y 163.

38. Vid. ARGOTE DE MOLINA, G. Opus cit. Págs. 157 y 163; también PAVON MALDONADO, B. Opus cit. Págs. 163-65.

39. SANCHEZ SAUS, R. Linajes sevillanos medievales Sevilla, 1991 Tomo I Pág. 172.

40. Vid., por ejemplo, IBIDEM Págs. 172-182 passim. y MATUTE Y GAVIRIA, J. Noticias relativas a la Historia de Sevilla Sevilla, 1886 Págs. 82-3. 
La cuestión pudiera haberse aclarado si llega a conservarse la inscripción en el anillo de arranque de la bóveda, sustituida hoy por una leyenda en letra gótica imitada que se pintó en 1919 haciendo referencia a las obras de restauración y nombrando al que por entonces era Hermano Mayor de la Cofradía de la Quinta Angustia ${ }^{41}$. Al menos conservamos la inscripción de la bóveda que comunica con la nave de la iglesia, cuya transcripción es la siguiente: "Esta capilla es del onrado cauallero Diego Gonzalez de Medina thesorero de la moneda de la casa de Burgos la qual capilla fizo para el e de los dineros de frai Garcia de Seuilla maestro en Santa theologia" ${ }^{42}$.

Efectivamente, de Diego González de Medina, veinticuatro y fiel ejecutor de Sevilla, nos consta que en el año de 1402 era Tesorero Mayor de la Casa de la Moneda de Burgos y que debió morir hacia $1415^{43}$. La datación de la capilla -al menos de su decoración hoy perdida ${ }^{44}$ —se ajusta hacia el año 1400 o poco después, dado que en la inscripción ya se manifiesta que poseía el cargo de Tesorero.

Pero esta capilla es la contigua a la que nos interesa, al parecer por la heráldica también relacionada con la familia Medina. Esta cronología sólo nos vale como apoyo de referencia, ya que la decoración pictórica que se estudia podría situarse poco antes o después impulsada por otro individuo nobiliar. La mayoría de los autores que han estudiado estas pinturas las sitúan, impulsados por consideraciones estilísticas y las desprendidas de las características arquitectónicas, hacia $1400{ }^{45}$. Aunque, en muchos casos, dejan abierto un resquicio a la posibilidad de remontarse a décadas anteriores, concretamente al reinado de $\mathrm{D}$. Pedro tan vinculado a la obra del Convento de San Pablo.

La referencia cronológica por la inscripción de la bóveda adjunta reafirma la hipótesis en la datación de hacia 1400 . No sería extraño que las pinturas pudieran ser algo anteriores y pensar en una fecha de fines del siglo XIV, volviendo así a la suposición del primer investigador de las mismas D. Francisco Murillo Herrera ${ }^{46}$. Sea como fuere estas pequeñas pinturas murales parecen involucrarse en el proceso constructivo —o reconstructivo a partir de antiguos muros almohades — de las en realidad tres capillas de la Quinta Angustia en torno a la fecha inmediatamente señalada, que poco después recibirían un repertorio decorativo y quizás simbólico según la preferencia de sus nobles patrocinadores. Ornato, motivos y estilística que concuerdan perfectamente con la simbiosis de elementos goticistas y mudéjares granadinos y toledanos coincidentes con los gustos de la época de Pedro I y con la venida a Sevilla de artesanos de estas procedencias atraídos por las obras del Alcázar, que sin duda dejarían sus secuelas artísticas en la capital hispalense.

41. RODRIGUEZ-CASO DOSAL, L. Anales de 1500 a 1976 de la Hermandad de la Quinta Angustia Opus cit. Pág. 120.

42. GUTIERREZ MORENO, P. Opus cit. Pág. 243.

43. SANCHEZ SAUS, R. Opus cit. Pág. 172.

44. Esta bóveda muestra en su zona inferior pintura roja que probablemente sea resto de ornato mural más complejo.

45. Vid., por ejemplo, GUTIERREZ MORENO, P. Opus cit. Pág. 245; GUERRERO LOVILLO, J. Opus cit. Pág. 126 y HERNANDEZ DIAZ, J. Opus cit. Pág. 210.

46. Vid. GUICHOT Y SIERRA, A. Opus cit. Tomo II Pág. 15. 


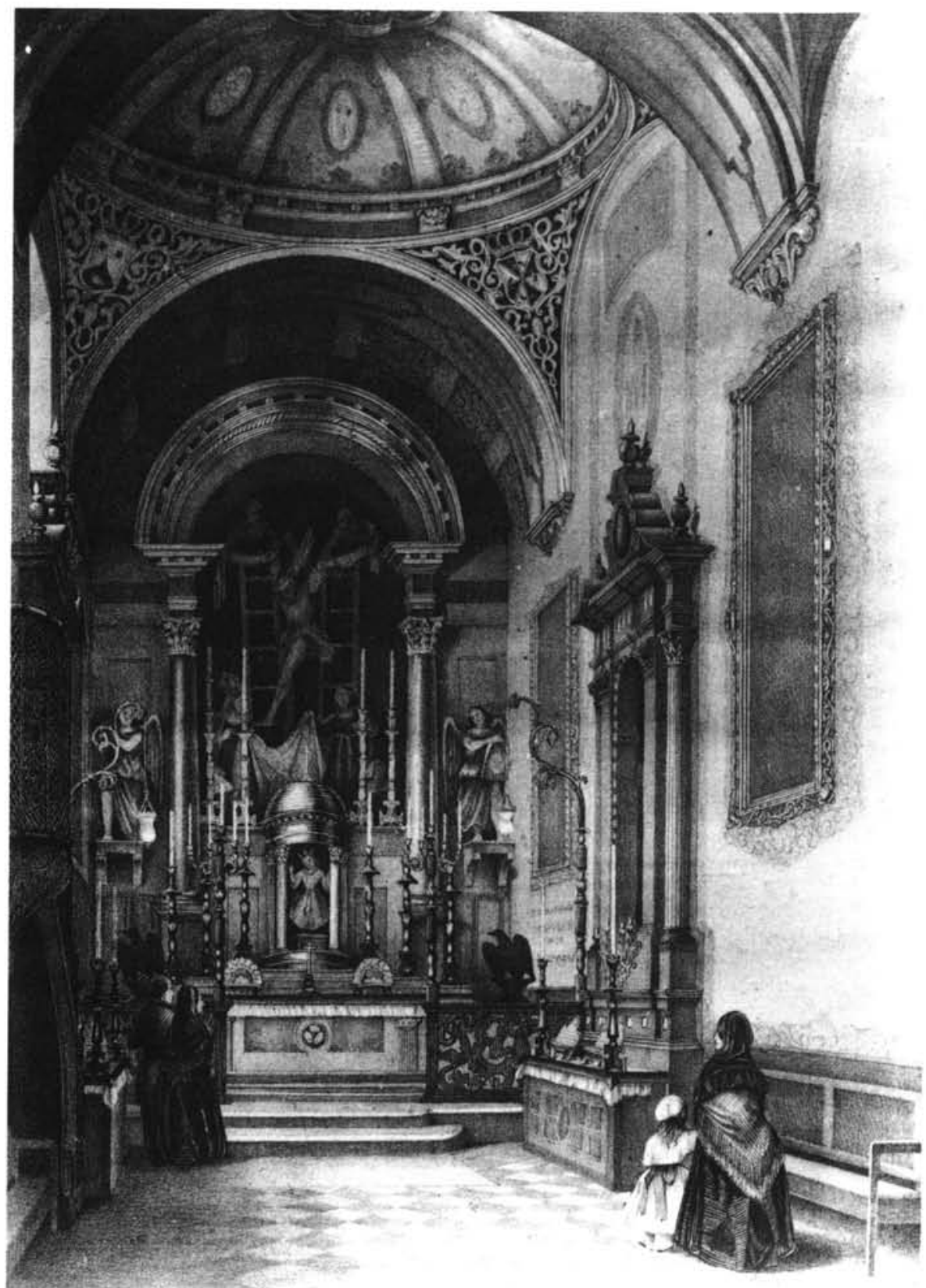

Lám. 1

Dibujo de Joaquín Guichot fechable a mediados del siglo XIX del interior de la Capilla de la Quinta Angustia (Archivo Fotográfico del Departamento de $\mathrm{H}^{2}$ del Arte. Universidad de Sevilla). 


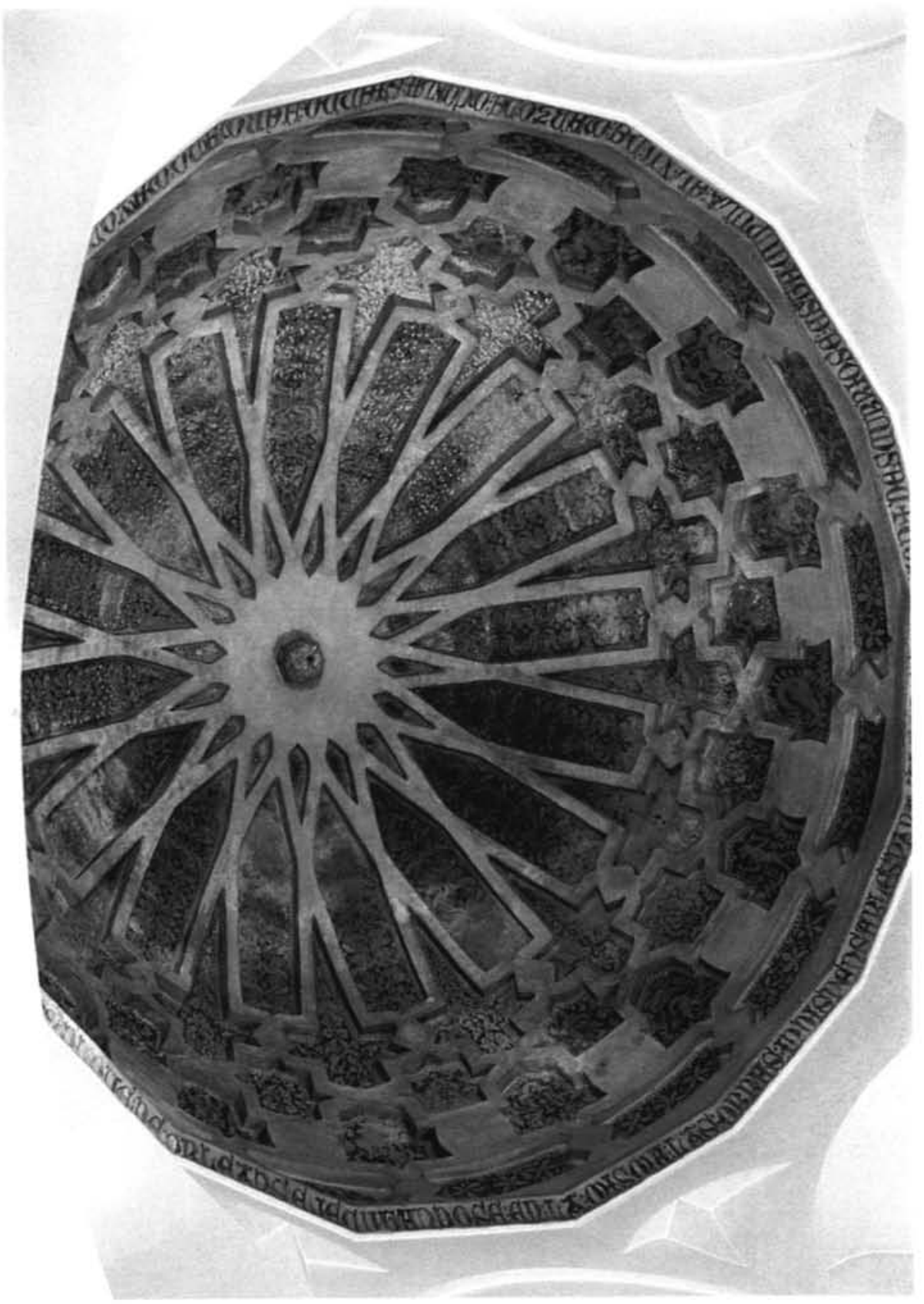

Lám. 2

Aspecto actual de la bóveda con sus pinturas (Fotografía del autor). 


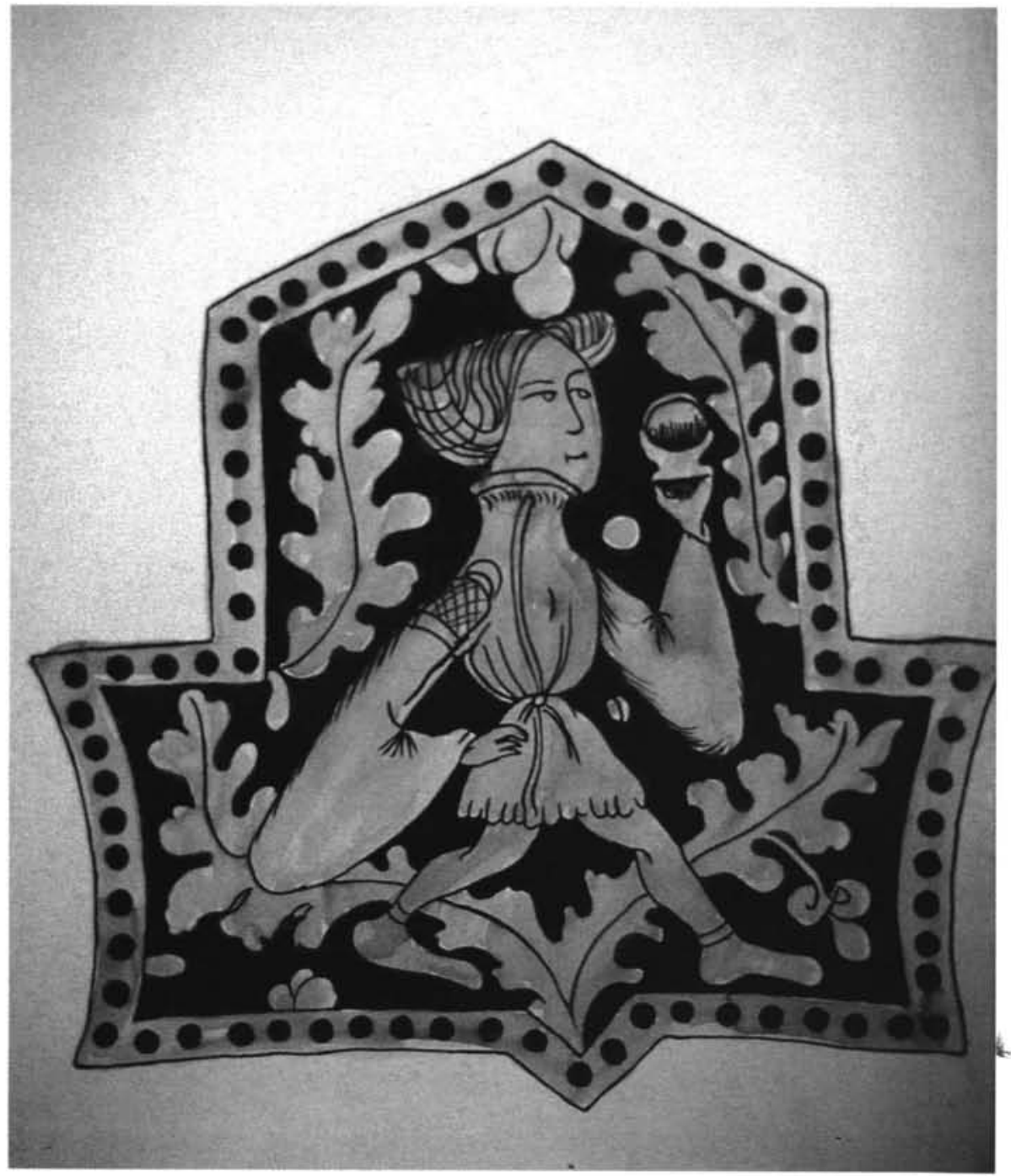

Lám. 3

Figura masculina (Acuarela depositada en el Archivo Fotográfico del Departamento de $\mathrm{H}^{2}$ del Arte. Universidad de Sevilla). 


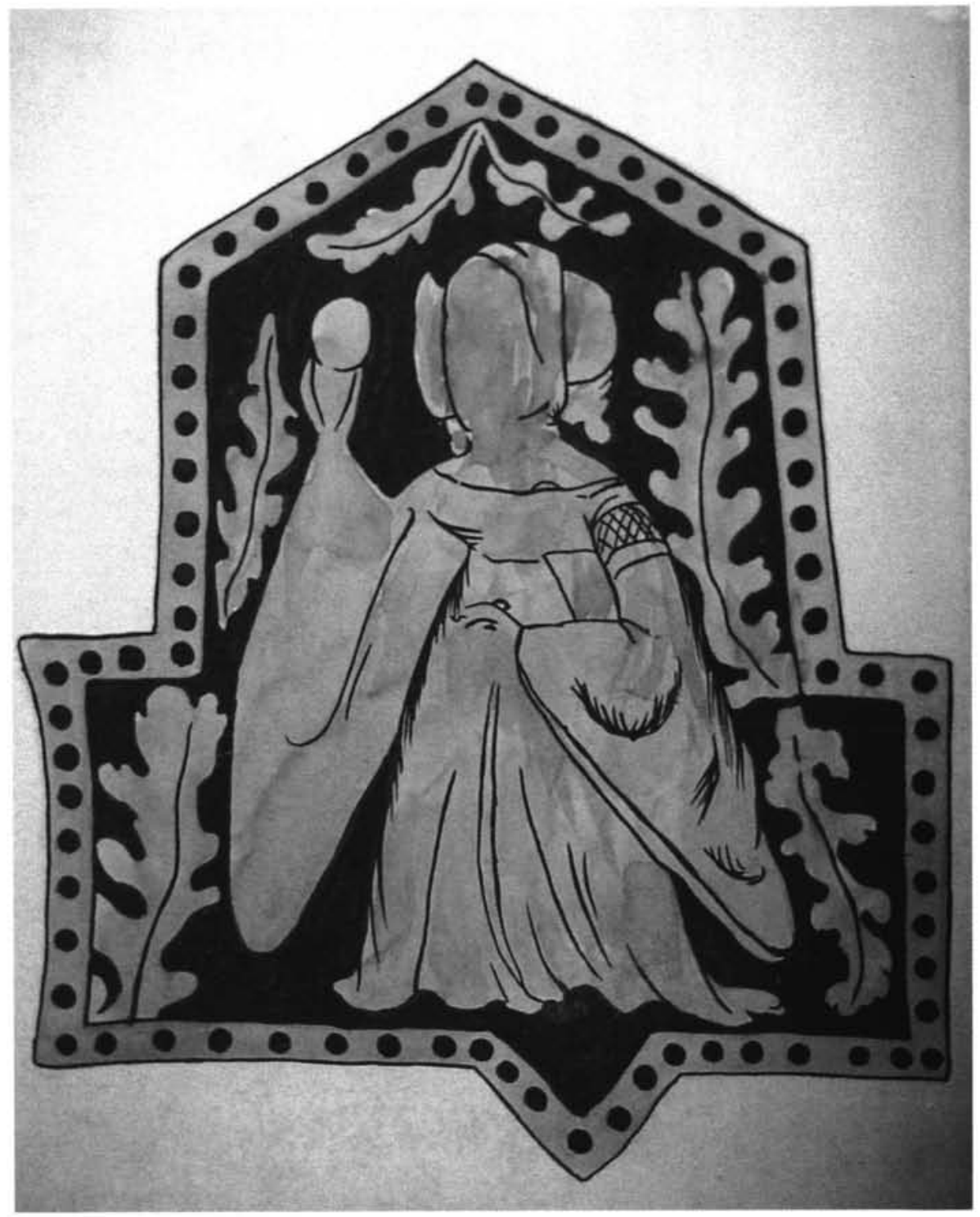

Lám. 4

Figura femenina (Idem). 


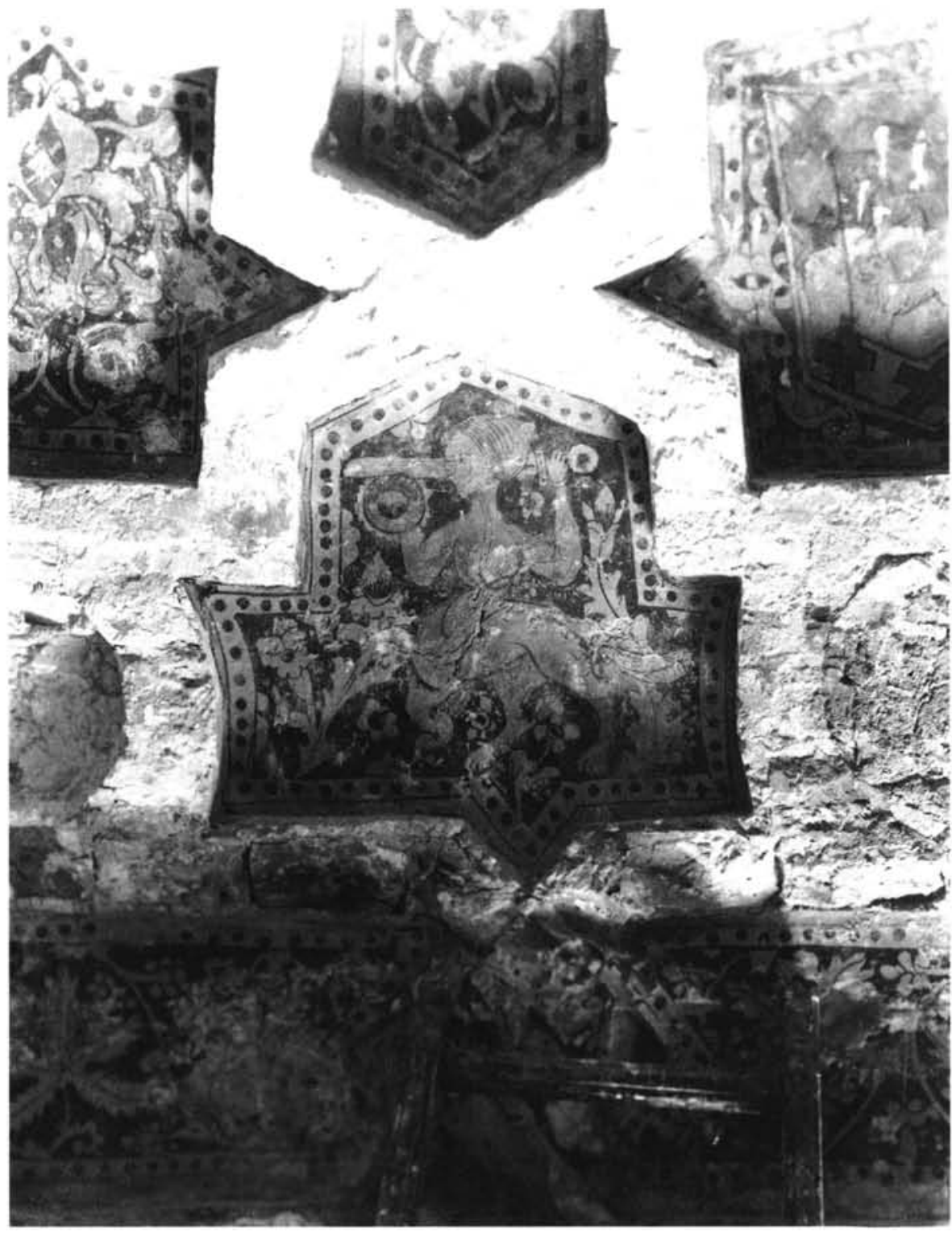

Lám. 5

Centauro de figura femenina (Fotografía Idem.) 


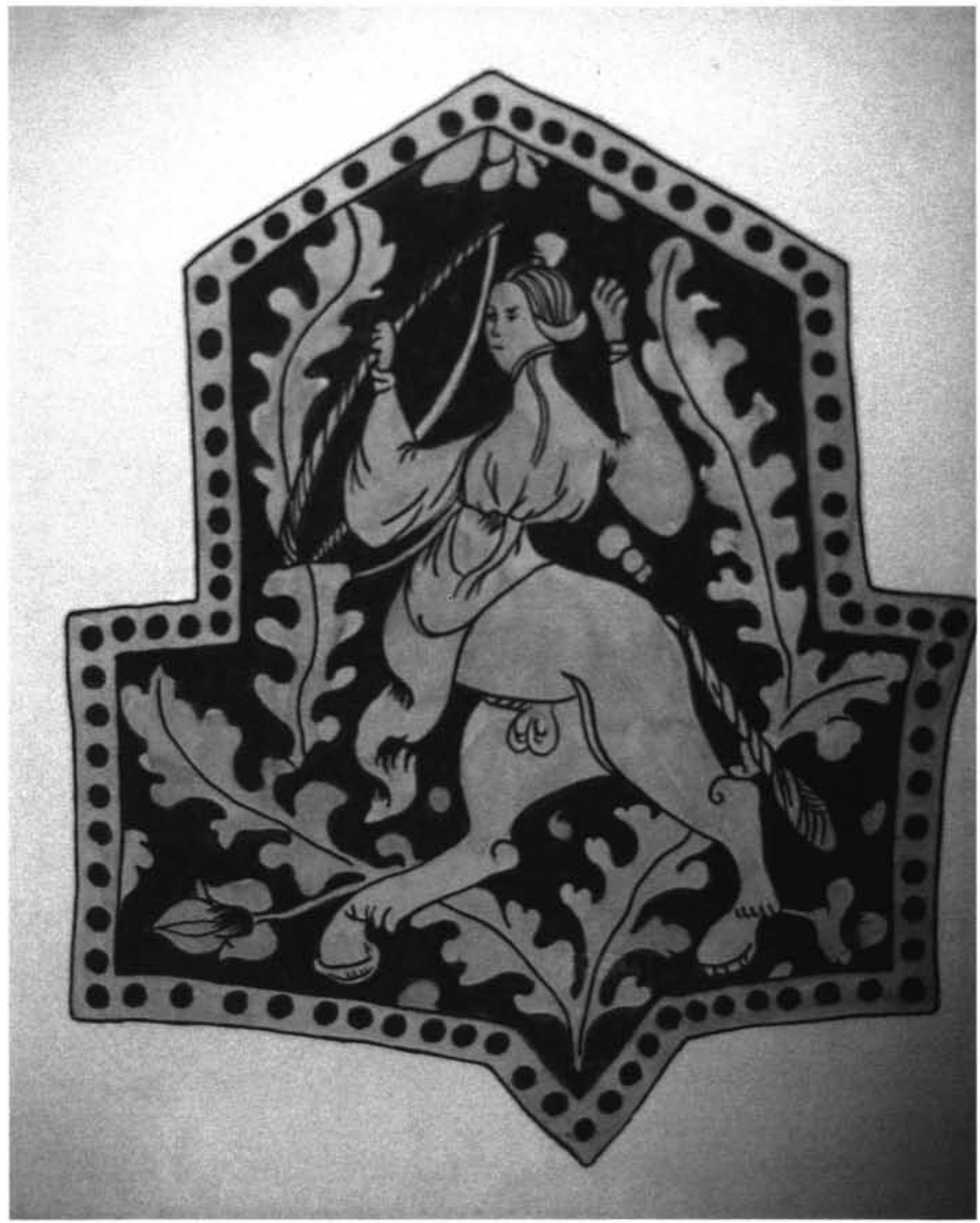

Lám. 6

Centauro de figura femenina (Acuarela Idem.) 


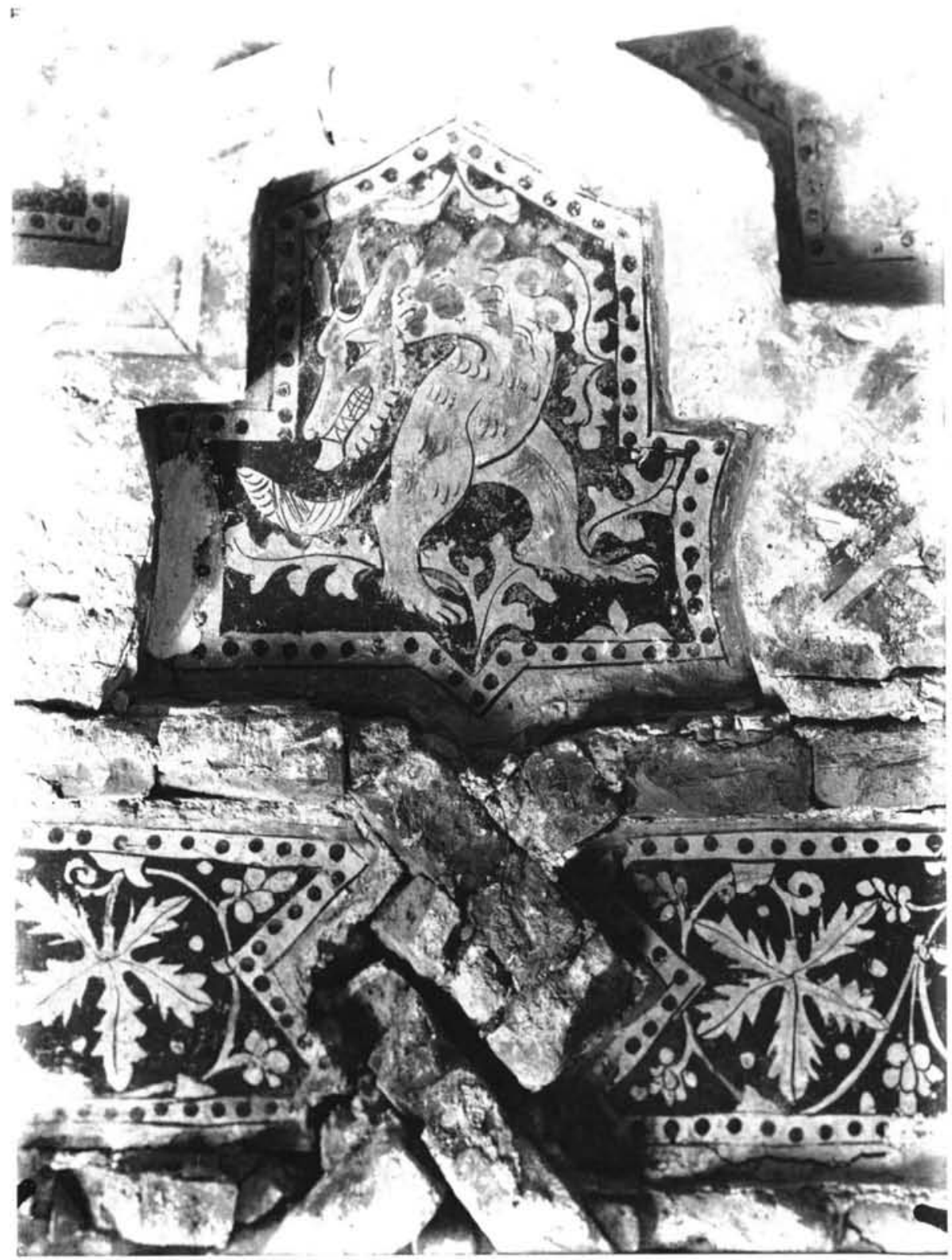

Lám. 7

Dragón sin alas (Fotografía Idem.) 


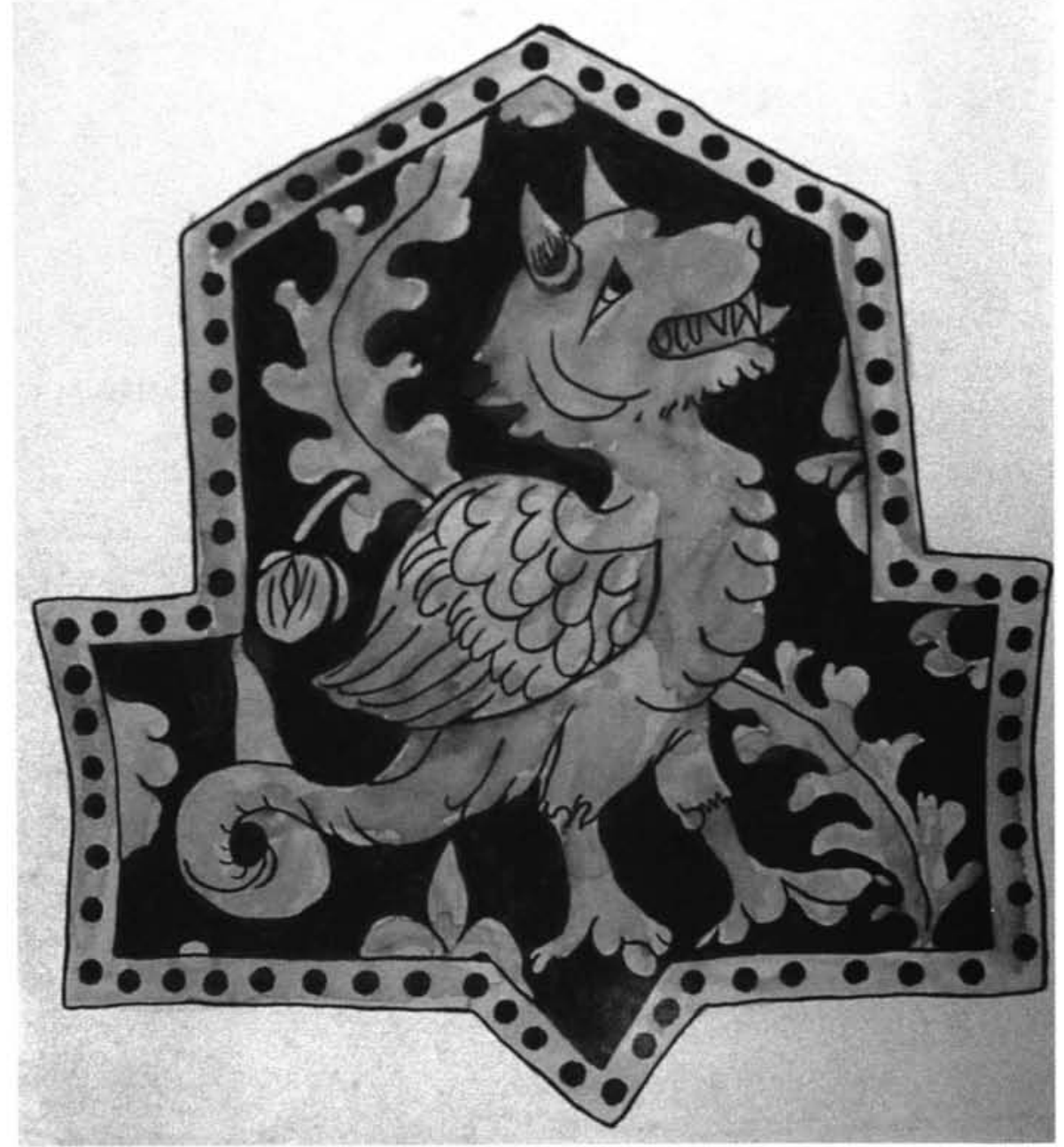

Lám. 8

Dragón alado (Acuarela Idem.) 


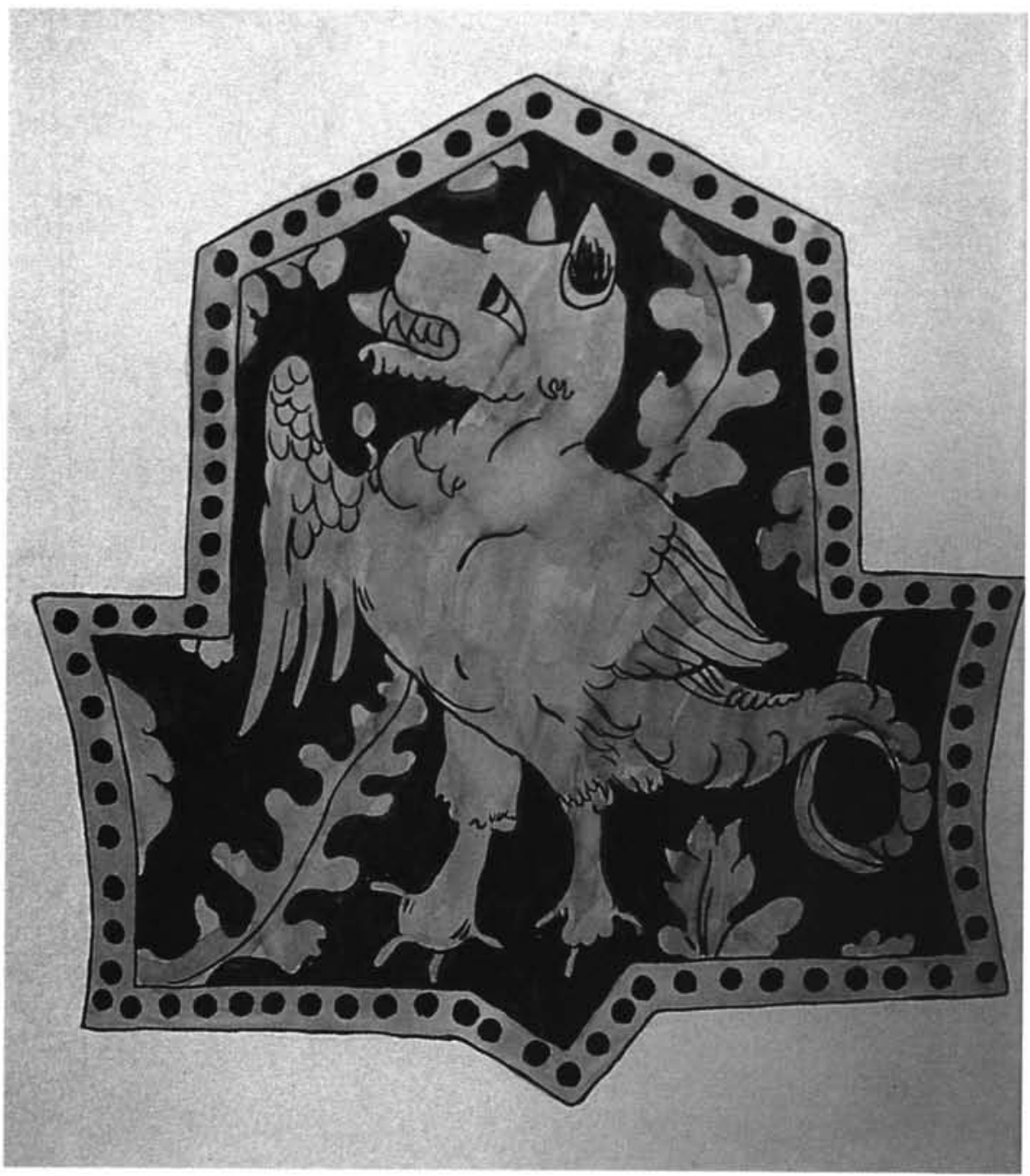

Lám. 9

Dragón alado (Acuarela Idem.) 


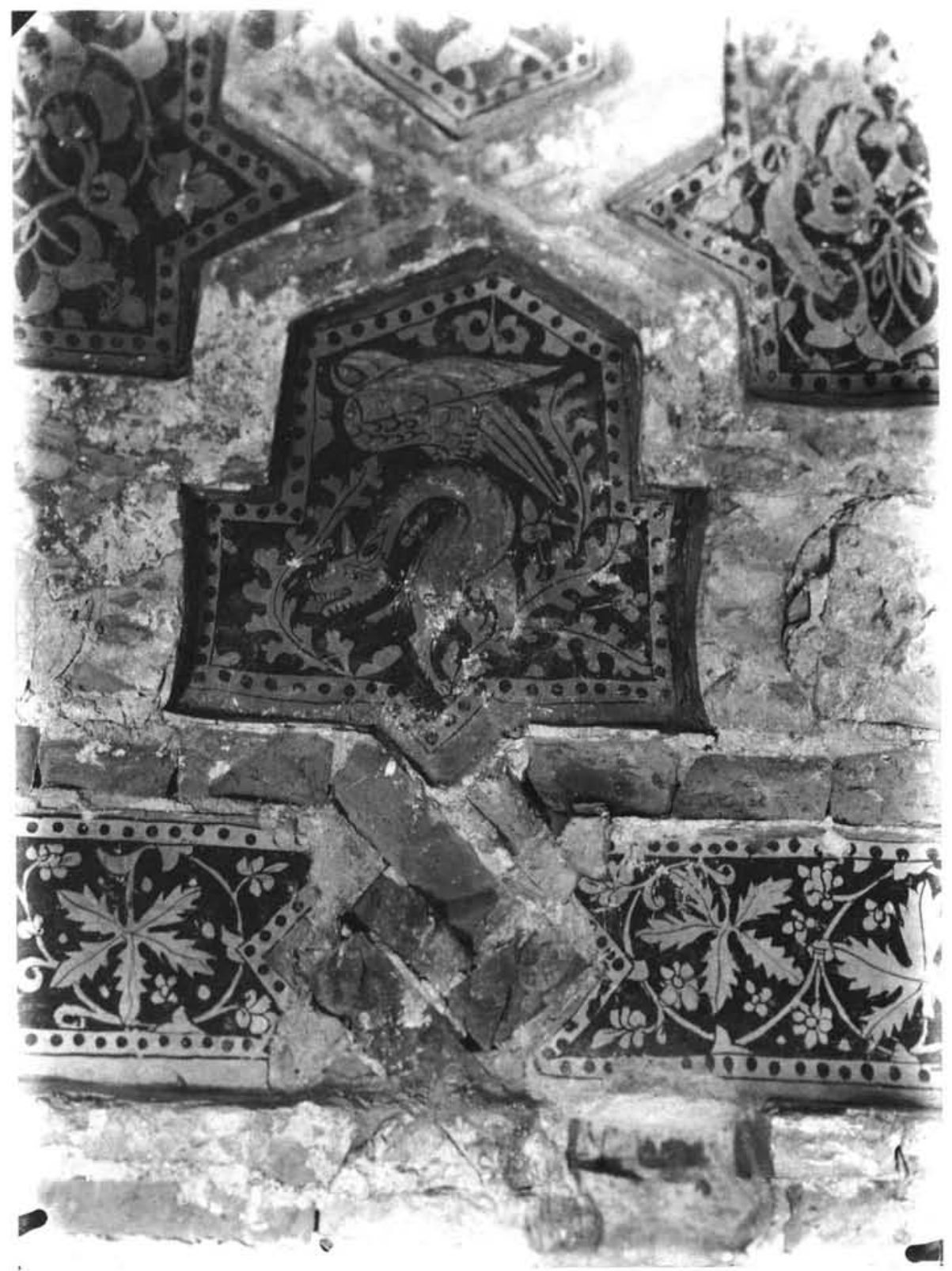

Lám. 10

Dragón alado (Fotografía Idem.) 


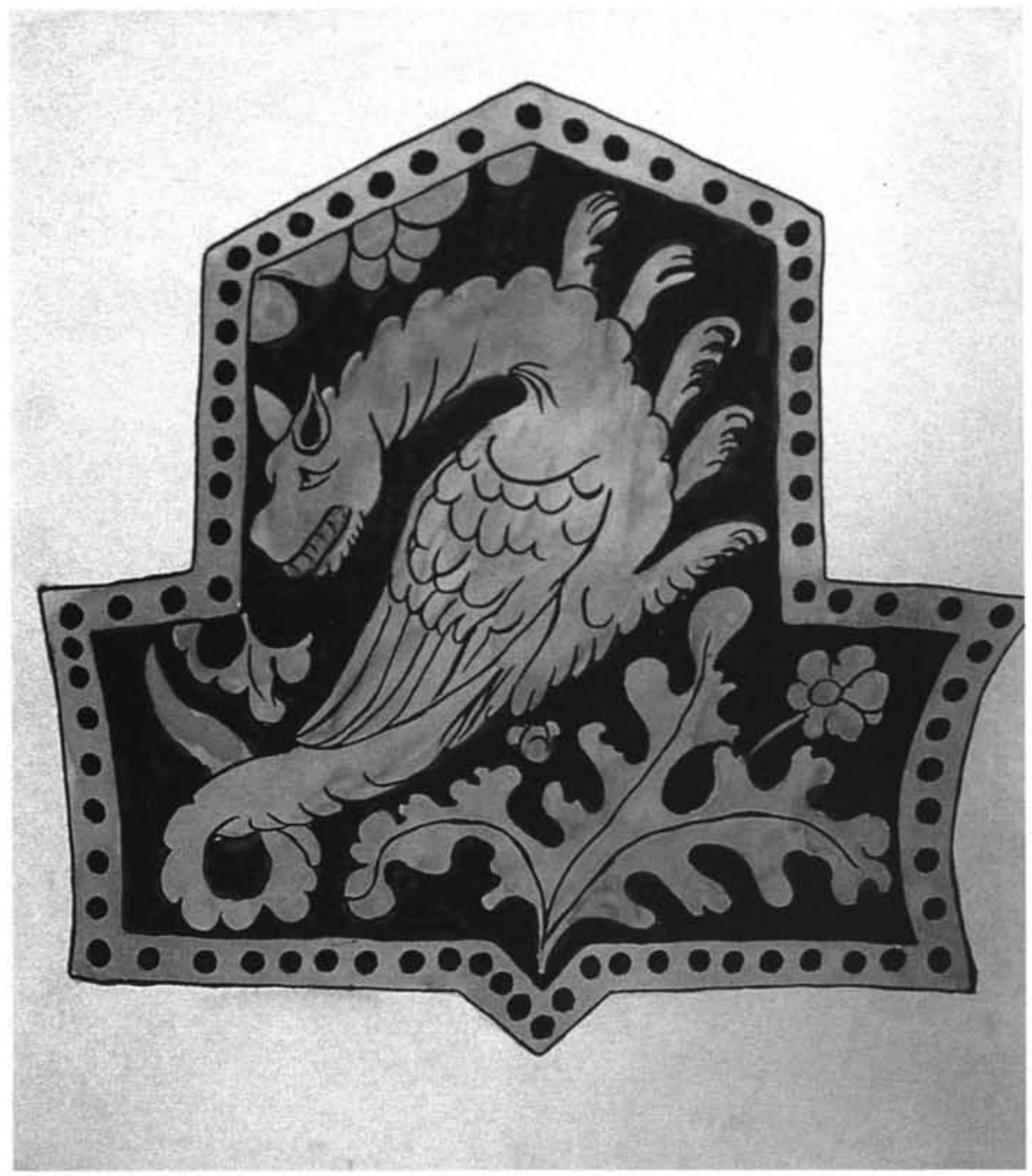

Lám. 11

Dragón alado (Acuarela Idem.) 


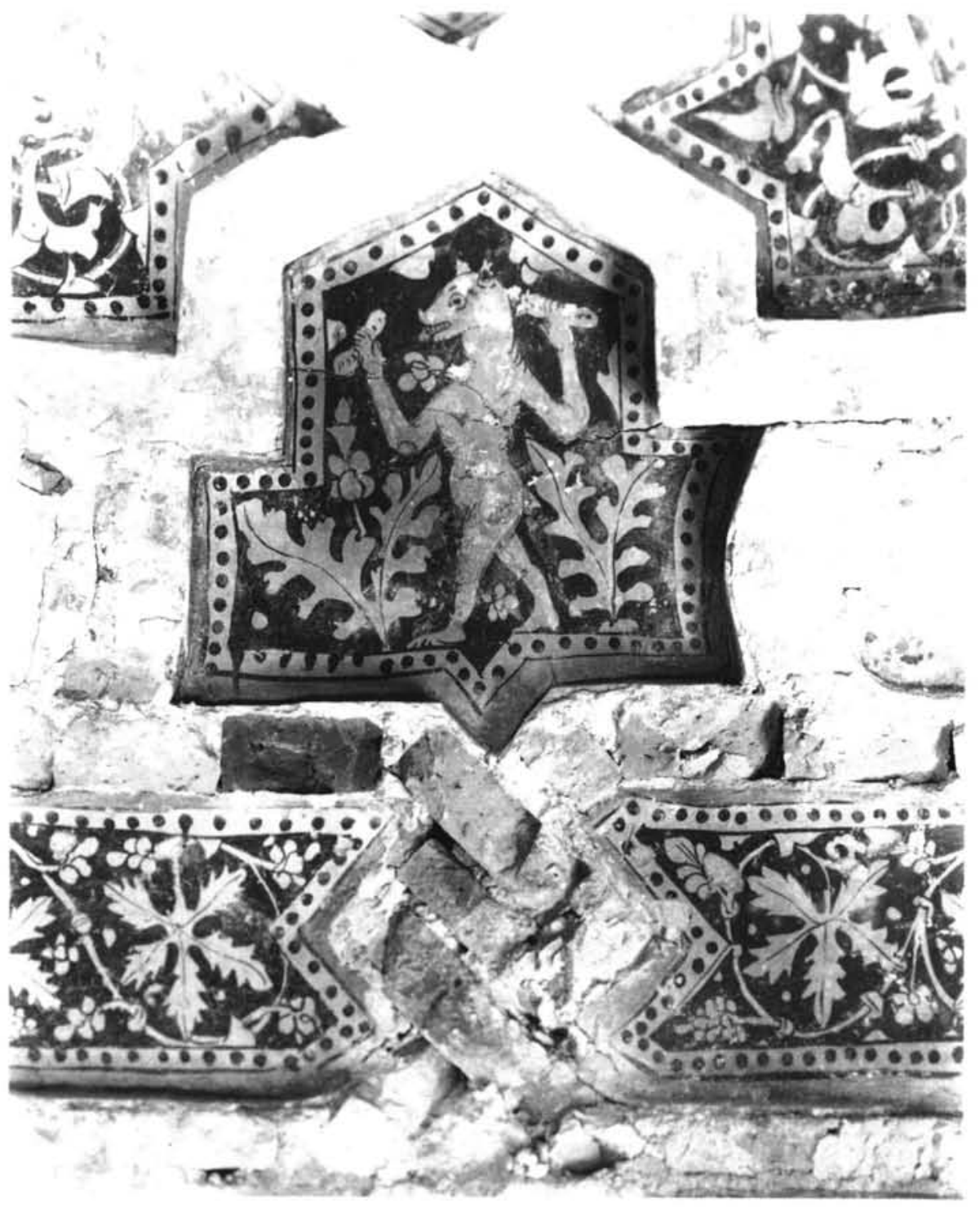

Lám. 12

Figura de cinocéfalo (Fotografía Idem.) 


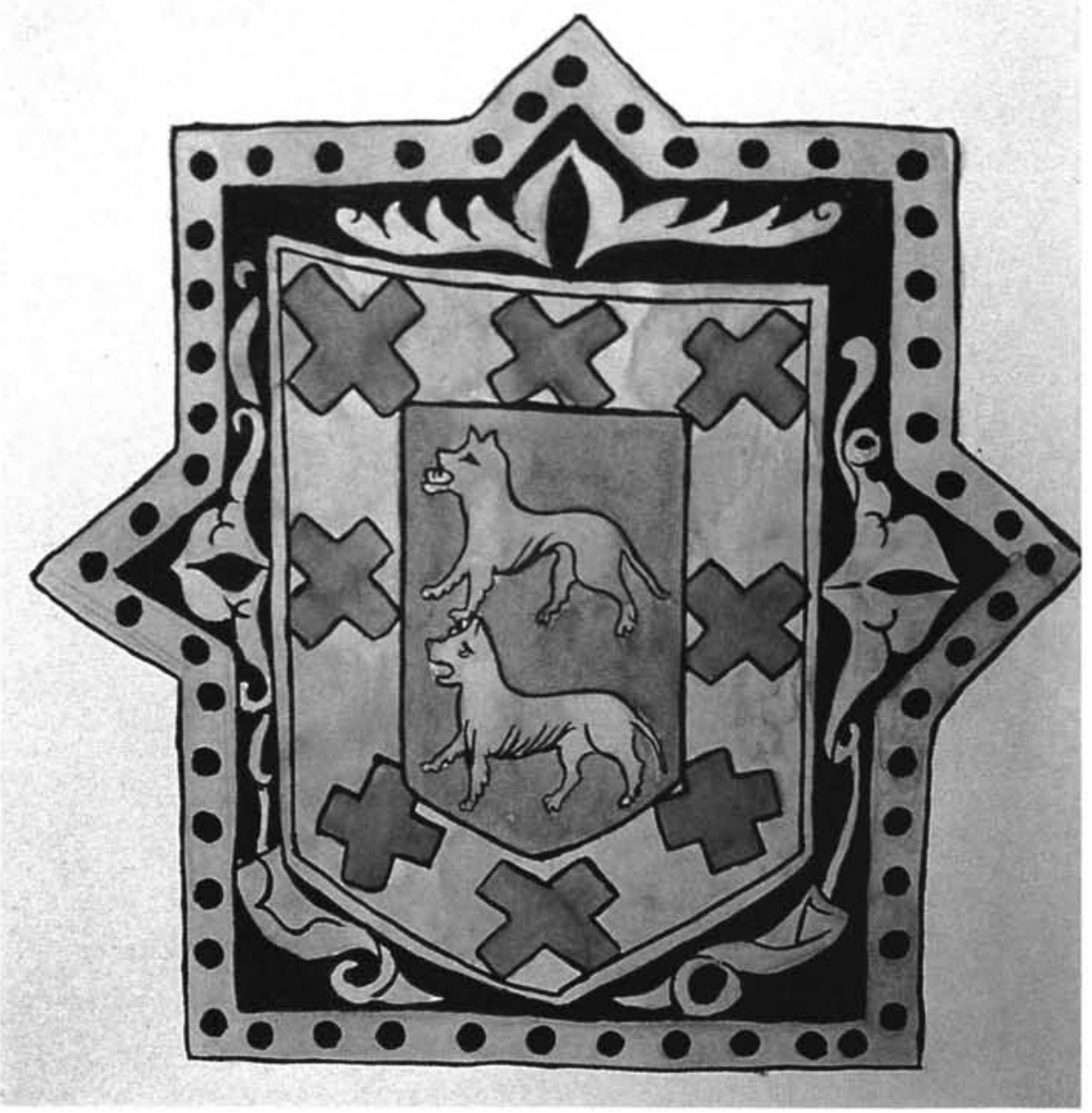

Lám. 13

Escudo de la familia Ayala (Acuarela Idem.) 


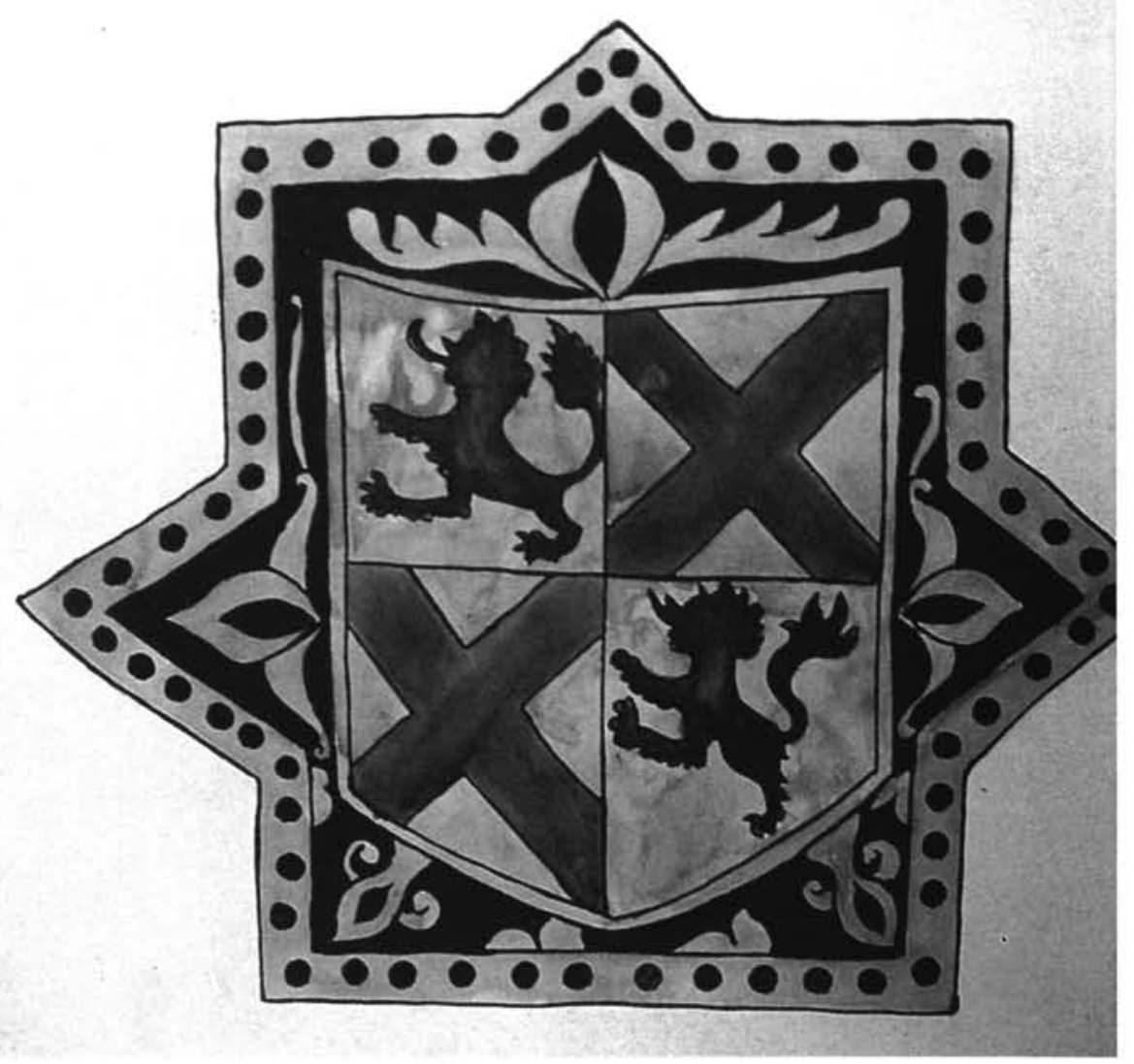

Lám. 14

Escudo de la familia Medina (Acuarela Idem.) 


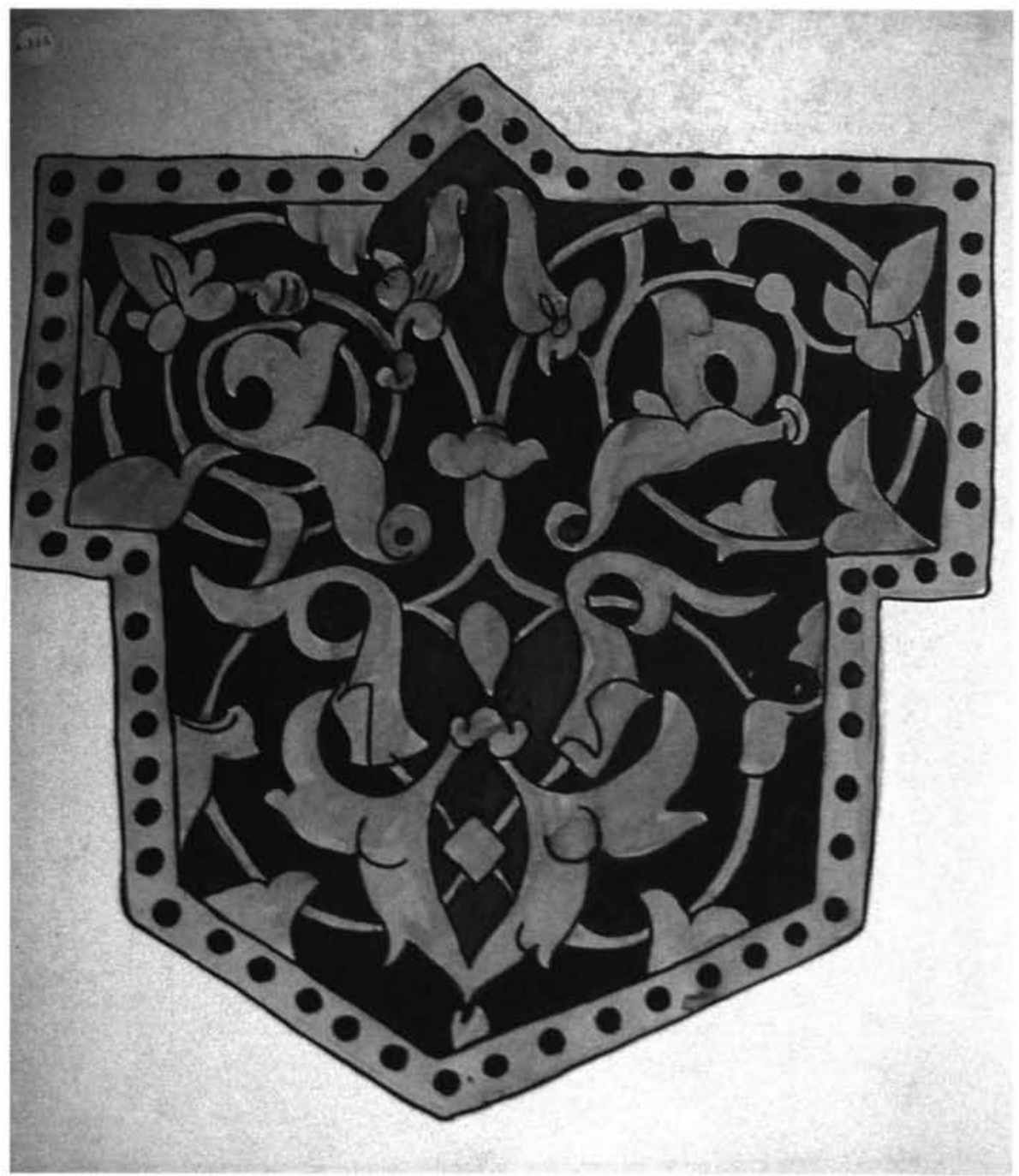

Lám. 15

Decoración vegetal de tipo mudéjar (Acuarela Idem.) 


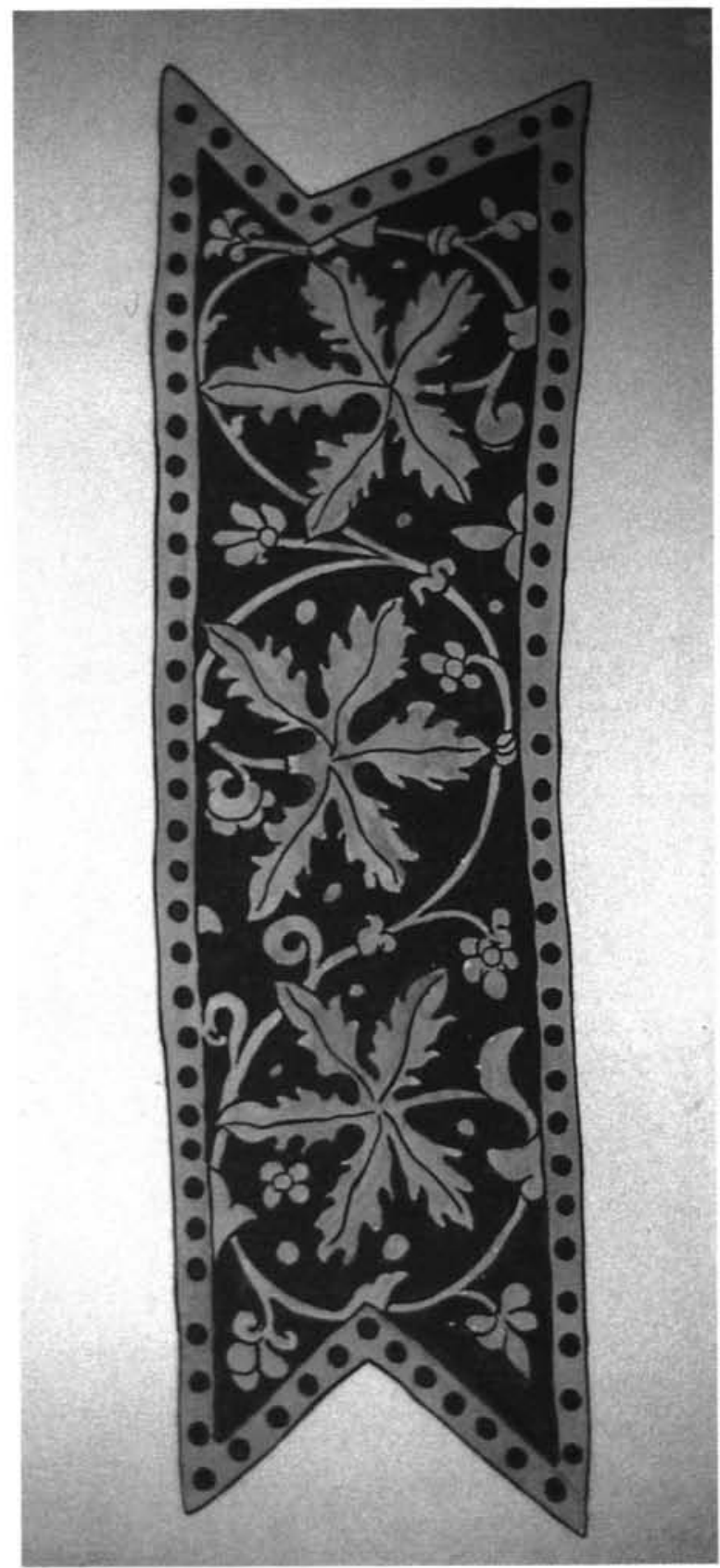

Lám. 16

Decoración vegetal goticista (Acuarela Idem.) 